\title{
Myelin: Methods for Purification and Proteome Analysis
}

\author{
Michelle S. Erwig, Dörte Hesse, Ramona B. Jung, Marina Uecker, \\ Kathrin Kusch, Stefan Tenzer, Olaf Jahn, and Hauke B. Werner
}

\begin{abstract}
Molecular characterization of myelin is a prerequisite for understanding the normal structure of the axon/ myelin-unit in the healthy nervous system and abnormalities in myelin-related disorders. However, reliable molecular profiles necessitate very pure myelin membranes, in particular when considering the power of highly sensitive "omics"-data acquisition methods. Here, we recapitulate the history and recent applications of myelin purification. We then provide our laboratory protocols for the biochemical isolation of a highly pure myelin-enriched fraction from mouse brains and for its proteomic analysis. We also supply methodological modifications when investigating posttranslational modifications, RNA, or myelin from peripheral nerves. Notably, technical advancements in solubilizing myelin are beneficial for gel-based and gel-free myelin proteome analyses. We conclude this article by exemplifying the exceptional power of label-free proteomics in the mass-spectrometric quantification of myelin proteins.
\end{abstract}

Key words Myelin, Oligodendrocyte, White matter, Density gradient ultracentrifugation, Mass spectrometry, Proteome/proteomics, Proteoform, Lipidome/lipidomics, Transcriptome/transcriptomics, Cyclic nucleotide phosphodiesterase (CNP), Proteolipid protein (PLP), Myelin basic protein (MBP), Cholesterol, Demyelination, Nerve conduction

\section{Introduction}

\begin{abstract}
About 65 years ago, the emergence of novel lipid extraction methods enabled the first biochemical analyses of myelin. Notably, Marjorie Lees and Jordi Folch developed a protocol to extract lipids from nervous tissue using a chloroform-methanol mixture [1]. Compared to the previously used ethyl alcohol and ester, chloroform-methanol has allowed extracting a much wider range of lipid species, enhanced purity, and less impact on the chemical nature of the lipids. When the method was applied to rat brains, the lipid extracts also contained an abundant protein that like lipids was soluble in chloroform-methanol mixtures but insoluble in aqueous
\end{abstract}


solutions [2]. Termed proteolipid protein (PLP), this protein is the most abundant constituent of central nervous system myelin [3-6] and associated with lipids [7-11]. Indeed, expression of PLP is required to enrich membrane cholesterol to the high levels normally found in central myelin [12].

More systematic molecular characterization of the entire myelin sheath required a method to enrich myelin from nervous tissue to a level of purity that was not achievable by chloroform-methanol extraction. It took over 15 years until such a protocol had evolved from classical approaches to fractionate entire brains by density centrifugation. Initially, myelin was found as an often-unwelcome contaminant of the nuclear fraction $[13,14]$. However, such approaches led to the insight that myelin membranes have the highest lipid content and thus the lowest hydrated density of any membrane in the nervous tissue. In an early attempt specifically directed to exploit this characteristic for enriching myelin from nervous tissue, Saul Korey and his colleagues homogenized subcortical white matter in low-density $(0.25 \mathrm{M})$ sucrose; before ultracentrifugation the homogenate was layered over sucrose of high and intermediate density (1.75 M and 0.5 M) [15]. Most myelin accumulated at the interface between $0.25 \mathrm{M}$ and $0.5 \mathrm{M}$ sucrose. Yet, the fraction also contained considerable amounts of cell debris and axonal fragments that were reduced only to a certain extent during a second ultracentrifugation, in which myelin floated up in a single layer of $1.0 \mathrm{M}$ sucrose.

A subsequent modification of this protocol resulted in improved purity by using $0.8 \mathrm{M}$ instead of $1.0 \mathrm{M}$ sucrose in the second ("floating-up") ultracentrifugation and replacing buffered salt solutions by water in the washing steps [16]. The use of water, a hypotonic solution, represents an osmotic shock, which we now know contributes considerably to separating myelin from the axonal plasma membrane and other cellular debris. In a next stage of methodological evolution, brain tissue was homogenized in $0.32 \mathrm{M}$ sucrose and layered over $0.66 \mathrm{M}$ sucrose for ultracentrifugation; then two osmotic shocks were followed by a second ultracentrifugation using a similar "spin-down" gradient [17]. Importantly, the high purity of the resulting myelin fraction was carefully scrutinized. Indeed, the myelin fraction displayed a high lipid and proteolipid content, and when observed by electron microscopy contained a high proportion of intact-appearing, multilayered myelin sheaths. Equally important, the preparation appeared essentially free of nuclei, mitochondria, blood vessels, cell debris, endoplasmic reticulum, and axonal remnants.

Finally, William Norton and Shirley Poduslo combined the advantageous-appearing conditions of the earlier protocols. Rat brains homogenized in $0.32 \mathrm{M}$ sucrose were layered on top of $0.85 \mathrm{M}$ sucrose; most material sedimented during ultracentrifugation. Indeed, a discrete myelin fraction accumulated at the 
interface, which was subsequently subjected to two osmotic shocks [18]. It is noteworthy that this protocol is commonly cited as "the" method to isolate myelin from nervous tissue despite the fact that it lacks a second ultracentrifugation step, the omission of which is disadvantageous for the purity [19] and enrichment [20] of myelin membranes as we now know. The most relevant procedural adaptations since 1973 thus include the reintroduction of the second ultracentrifugation step, as well as replacing the previously used Dounce homogenizer by a high-shear disperser (Ultra-Turrax) [21] and the supplementation of solutions with protease inhibitors.

Together, by taking advantage of its low density, myelin can be highly enriched from homogenized nervous tissue using sucrose density gradient ultracentrifugation. Other cellular compartments and debris are almost quantitatively removed. Indeed, the method has enabled a fair yield of highly purified myelin across a number of laboratories despite moderate procedural differences. Considering the long-standing interest in myelin's composition of proteins [22-25] and lipids [26-28] it is not surprising that the myelin fraction has more recently been the subject of modern systematic approaches, thereby laying the foundations for myelin proteomics [4] and lipidomics [29]. Notably, a recent RNAseqanalysis of myelin purified from mouse brains at various ages has identified an unpredictably large transcript pool enriched in CNS myelin that is intimately interrelated to the myelin proteome but quite dissimilar to the transcriptomes of oligodendrocytes and brain regions [30]. The findings imply that the selective incorporation of transcripts into the myelin compartment enables both local adaptation and turnover of the myelin sheath. Yet, among the conceivable systematic approaches to myelin, proteome analysis has been most frequently used so far ([31] and references therein; [32-34]).

In the following, we provide our laboratory protocols for myelin purification from the mouse central nervous system, as well as modifications for the application to peripheral nerves or for RNA analysis. We then focus on techniques for gel-based and gel-free myelin proteome analysis. We conclude this article by exemplifying the exceptional power of label-free proteomics in the relative quantification of myelin proteins. We refer the reader to original articles for the related topic of proteome analyses of isolated oligodendrocytes [35-38], to earlier review articles for proteome analysis in the context of white matter disorder $[39,40]$ and to general overviews about the mechanisms and functions of myelination [41-44], which we do not cover extensively. 


\section{Materials}

\subsection{Biochemical \\ Purification of Central Nervous System Myelin}

2.1.1 Preparations (At Least One Day Ahead of the Experiment)

2.1.2 Preparations (On the Day of the Experiment)

\subsubsection{Tissue Preparation}

2.1.4 First Sucrose

Density Gradient

\subsubsection{Washing}

2.1.6 First Osmotic Shock

2.1.7 Second Osmotic Shock

2.1.8 Second Sucrose Density Gradient

2.1.9 Washing
1. $500 \mathrm{~mL}$ ddH ${ }_{2} \mathrm{O}$.

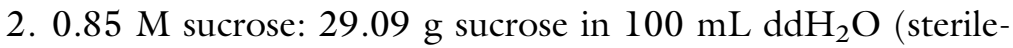
filtered, cool to $4{ }^{\circ} \mathrm{C}$ ).

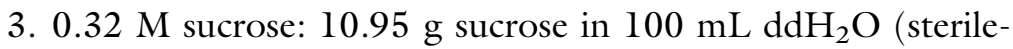
filtered, cool to $4{ }^{\circ} \mathrm{C}$ ).

4. Thermo Scientific WX+ Ultracentrifuge (or equivalent).

5 . TH64l swing-out rotor (or equivalent).

6. 6 corresponding adaptors.

1. Thermo Scientific WX+ Ultracentrifuge (or equivalent).

2. Protease inhibitors to $50 \mathrm{~mL} 0.32 \mathrm{M}$ sucrose (dissolve at $4{ }^{\circ} \mathrm{C}$, then keep on ice).

3. Large ice bucket.

1. 6 Beckman centrifuge tubes, Ultra-clear, $14 \times 89 \mathrm{~mm}$.

2. IKA T10 basic Ultra-Turrax (or equivalent).

3. $70 \% \mathrm{EtOH}$.

4. $\mathrm{ddH}_{2} \mathrm{O}$.

1. 6 Beckman centrifuge tubes, Ultra-clear, $14 \times 89 \mathrm{~mm}$.

1. 6 Beckman centrifuge tubes, Ultra-clear, $14 \times 89 \mathrm{~mm}$.

2. Forceps.

3. Pasteur pipette.

1. Paper tissue.

1. Paper tissue.

2. Protease inhibitors to $50 \mathrm{~mL} 0.32 \mathrm{M}$ sucrose (dissolve at $4{ }^{\circ} \mathrm{C}$, then keep on ice).

1. 6 Beckman centrifuge tubes on ice.

2. Paper tissue.

3. $10 \times$ TBS: $1370 \mathrm{mM} \mathrm{NaCl}, 200 \mathrm{mM}$ Tris/HCl, $\mathrm{pH} 7.4,4{ }^{\circ} \mathrm{C}$.

1. 6 Beckman centrifuge tubes on ice.

2. Pasteur pipette.

3. $10 \times$ TBS: $1370 \mathrm{mM} \mathrm{NaCl}, 200 \mathrm{mM}$ Tris/HCl, $\mathrm{pH} 7.4,4^{\circ} \mathrm{C}$.

4. $-80{ }^{\circ} \mathrm{C}$ freezer. 
2.2 1D-Gel

Separation of Myelin for Proteome Analysis

2.2.1 1D-SDS-PAGE

2.2.2 Gel Staining

2.3 2D-IEF/SDSPAGE Separation of Myelin for Proteome Analysis

2.3.1 Delipidation / Precipitation/Solubilization

2.3.2 Rehydration/ Isoelectric Focusing
1. Precast Bis-Tris $4-12 \%$ gradient gels $(8 \times 8 \mathrm{~cm}, 1 \mathrm{~mm}$ gel thickness, NuPAGE, Thermo Fisher Scientific) OR Trisglycine $8-16 \%$ gradient gels $(7 \times 8 \mathrm{~cm}, 1 \mathrm{~mm}$ gel thickness, TG PRiME, Serva).

2. Running buffer containing 2-(N-Morpholino)ethanesulfonic acid OR 3-( $N$-morpholino)propanesulfonic acid (MOPS) buffer system (NuPAGE gels) OR Tris-glycine buffer system (TG PRiME gels).

3. 5-10 $\mu \mathrm{g}$ per lane of purified myelin.

1. Gel fixative: $40 \%(\mathrm{v} / \mathrm{v})$ ethanol, $10 \%(\mathrm{v} / \mathrm{v})$ acetic acid.

2. $\mathrm{ddH}_{2} \mathrm{O}$.

3. Dye stock solution: $2 \%(\mathrm{w} / \mathrm{v})$ orthophosphoric acid, $10 \%$ $(\mathrm{w} / \mathrm{v})$ ammonium sulfate, $0.1 \%(\mathrm{w} / \mathrm{v})$ Coomassie Brilliant Blue (CBB) G-250. Completely dissolve $20 \mathrm{~g}$ orthophosphoric

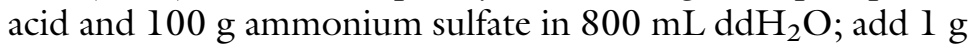
of CBB G-250 while stirring; fill up to $1 \mathrm{~L}$ with $\mathrm{ddH}_{2} \mathrm{O}$. Prepare stock solution $\geq 24$ h before staining; do not filter. Dye working solution: $80 \%(\mathrm{v} / \mathrm{v})$ dye stock solution, $20 \%(\mathrm{v} / \mathrm{v})$ methanol (prepare dye working solution just before use; add methanol while stirring of the stock solution).

1. $150 \mu \mathrm{L}$ of purified myelin (typical protein concentration $\sim 4 \mu \mathrm{g} / \mu \mathrm{L})$.

2. $2 \times 1.5 \mathrm{~mL}$ tube (preferably Eppendorf Safe-Lock).

3 . vortex.

4. $600 \mu \mathrm{L}$ methanol.

5. $300 \mu \mathrm{L}$ chloroform.

6. $450 \mu \mathrm{L} \mathrm{ddH}{ }_{2} \mathrm{O}$.

7. Centrifuge, e.g., Eppendorf 5415 with rotor F45-24-11 or equivalent.

8. Pipet.

9. Nitrogen stream.

10. Homogenization buffer: $30 \mathrm{mM}$ Tris- $\mathrm{HCl} \mathrm{pH} 9.0,7 \mathrm{M}$ urea, $2 \mathrm{M}$ thiourea, 2\% ASB-14.

1. IPG-strip (24 cm pH 3-12 NL, Serva).

2. IPGphor (GE Healthcare) or a Protean il2 (BioRad) IEF system.

3. $300 \mu \mathrm{g}$ protein per IPG-strip.

4. Rehydration buffer I: $7 \mathrm{M}$ urea, $2 \mathrm{M}$ thiourea, 2\% ASB-14, 1\% ampholytes (Serva), $30 \mathrm{mM}$ DTT.

5. Sonicator. 
2.3.3 SDS-PAGE

\subsection{Filter-Aided Sample Preparation (FASP) for Gel-Free Myelin Proteome Analysis}

2.4.1 Procedure
6. Shaker.

7. Rehydration buffer II: $7 \mathrm{M}$ urea, $2 \mathrm{M}$ thiourea, 2\% ASB-14, $0.5 \%$ ampholytes (Serva), 1.2\% DeStreak (GE Healthcare) or equivalent reagents based on organic disulfides.

8. Centrifuge (e.g., Eppendorf 5415 with rotor F45-24-11 or equivalent).

9. Mineral oil.

10. Water-wetted paper pads.

$10-15 \%$ acrylamide gradient gels $(25.5 \times 20 \mathrm{~cm}$, gel thickness $0.65 \mathrm{~mm})$.

Per sample:

1. $10 \mu \mathrm{g}$ of purified myelin.

2. DTT: $1 \mathrm{M}$ stock solution in water, store $200 \mu \mathrm{L}$ aliquots at $-20{ }^{\circ} \mathrm{C}$.

3. Lysis buffer: $7 \mathrm{M}$ urea, $2 \mathrm{M}$ thiourea, 0.1 $\mathrm{M}$ Tris $\mathrm{pH} 8.5$, store at $-20{ }^{\circ} \mathrm{C}$. Add $1 \%$ ASB- 14 or $2 \%$ CHAPS and $10 \mathrm{mM}$ DTT shortly before use.

4. Iodoacetamide: $450 \mathrm{mM}$ stock solution in water, prepare shortly before use, dilute 1:10 in urea buffer w/o DTT.

5. Shaker at $37^{\circ} \mathrm{C}$.

6. Filter unit (e.g., Merck Millipore Microcon-30 kDa Centrifugal Filter or equivalent).

7. $100 \mu \mathrm{L} 1 \%(\mathrm{v} / \mathrm{v})$ formic acid.

8. Urea buffer: $8 \mathrm{M}$ urea, $0.1 \mathrm{M}$ Tris $\mathrm{pH} 8.5$, store at $-20{ }^{\circ} \mathrm{C}$. Add $10 \mathrm{mM}$ DTT just before use (do not add DTT when diluting iodoacetamide).

9. Centrifuge $(11,000 \times \mathscr{g}, \mathrm{RT})$ or a vacuum manifold $(\Delta 600$ mbar, RT).

10. Sonicator.

11. $100 \mu \mathrm{L} 45 \mathrm{mM}$ iodoacetamide in urea buffer (prepare freshly just before use from $450 \mathrm{mM}$ stock solution in water).

12. $3 \times 200,300$ and $450 \mu \mathrm{L} 50 \mathrm{mM}$ ammonium bicarbonate, $10 \%$ $(\mathrm{v} / \mathrm{v})$ acetonitrile.

13. $40 \mu \mathrm{L}$ of trypsin working solution $(0.01 \mu \mathrm{g} / \mu \mathrm{L}), 50 \mathrm{mM}$ ammonium bicarbonate/ $10 \%$ acetonitrile.

14. $40 \mu \mathrm{L} 50 \mathrm{mM}$ ammonium bicarbonate in water.

15. $40 \mu \mathrm{L} 1 \%(\mathrm{v} / \mathrm{v})$ trifluoroacetic acid (TFA) in water.

16. $1.5 \mathrm{~mL}$ low protein-binding tubes (e.g., Eppendorf LoBind or equivalent). 
17. $2 \mu \mathrm{L}$ Yeast Enolase 1 digestion standard OR Hi3 EColi standard (Waters) $(100 \mathrm{fmol} / \mu \mathrm{L})$.

18. Glass autosampler vial for LC-MS analysis.

\section{Methods}

\subsection{Biochemical Purification of Central Nervous System Myelin}

\subsubsection{Preparations} (At Least One Day Ahead of the Experiment)

\subsubsection{Preparations} (on the Day of the Experiment)

\subsubsection{Tissue Preparation}

3.1.4 First Sucrose Density Gradient
1. Cool $500 \mathrm{~mL}$ ddH $\mathrm{H}_{2} \mathrm{O}$ to $4{ }^{\circ} \mathrm{C}$.

2. Prepare sucrose solutions, filter-sterilize them, and cool to $4{ }^{\circ} \mathrm{C}$.

3. Cool rotor and adaptors to $4{ }^{\circ} \mathrm{C}$.

1. Cool centrifuge to $4{ }^{\circ} \mathrm{C}$.

2. Add protease inhibitors to $50 \mathrm{~mL} 0.32 \mathrm{M}$ sucrose (dissolve at $4{ }^{\circ} \mathrm{C}$, then keep on ice).

1. Cool 6 Beckman Centrifuge tubes on ice.

2. Freshly dissect brain or spinal cord of mice (see Notes $\mathbf{1}$ and 2 ).

3. Transfer half a brain or one spinal cord into $5 \mathrm{~mL} 0.32 \mathrm{M}$ sucrose in one of the precooled Beckman centrifuge tubes.

4. Homogenize the tissue using IKA T10 basic Ultra-Turrax (Speed 3).

5. Clean the Ultra-Turrax thoroughly after each sample with $70 \%$ EtOH and $\mathrm{ddH}_{2} \mathrm{O}$ ( see Note 3 ).

1. Place additional 6 Beckman centrifuge tubes on ice.

2. Transfer $6 \mathrm{~mL}$ of cold $0.85 \mathrm{M}$ sucrose into each of the new tubes.

3. Carefully and slowly layer the homogenate (in $0.32 \mathrm{M}$ sucrose) on top of the $0.85 \mathrm{M}$ sucrose (Fig. 1) (see Note 4).

4. Fill one tube with cold $0.32 \mathrm{M}$ sucrose up to $0.5 \mathrm{~cm}$ below the tube edge and tare the other tubes with $0.32 \mathrm{M}$ sucrose exactly to the same weight (max. difference $0.01 \mathrm{~g}$ ) ( see Note 5 ).

5. Centrifuge at $75,000 \times g$ for $30 \mathrm{~min}$ at $4{ }^{\circ} \mathrm{C}$ (rotor TH64l at 24,400 rpm, acceleration 7, deceleration 7); always wait for vacuum.

6. Crudely purified myelin accumulates at the $0.32 / 0.85 \mathrm{M}$ sucrose interface as fluffy cloud (Fig. 1). The crude myelin fraction appears whitish if mice were transcardially perfused with physiological salt solution or orange-to-reddish if not. 


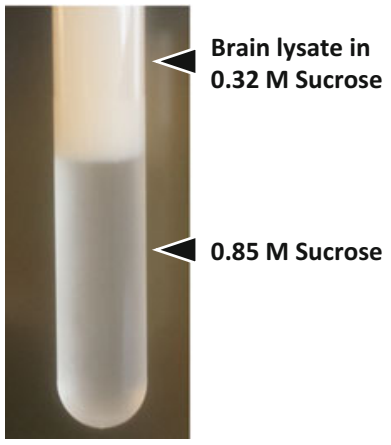

Brain lysate

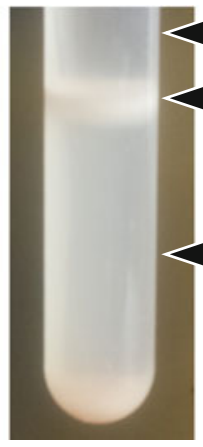

$0.32 \mathrm{M}$ Sucrose

Crude myelin

$0.85 \mathrm{M}$ Sucrose

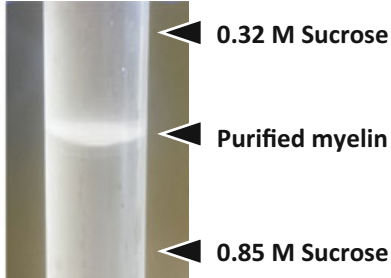

Gradient 1

\section{Osmotic shocks}

Fig. 1 To isolate CNS myelin, nervous tissue is first homogenized in $0.32 \mathrm{M}$ sucrose (see method 1). The homogenate is layered over $0.85 \mathrm{M}$ sucrose (image on the left) and subjected to sequential sucrose density gradient centrifugation, intermitted by osmotic shocks. During ultracentrifugation, the myelin-enriched lightweight membrane fraction accumulates at the interface

\subsubsection{Washing}

3.1.6 First Osmotic Shock
1. After each centrifugation step, place the adaptors on ice as vertically as possible.

2. Place 6 new Beckman centrifuge tubes on ice.

3. Carefully remove centrifuge tubes from the adaptor (forceps may help).

4. Collect the interface with a Pasteur pipette (be careful and try to collect as little of the $0.85 \mathrm{M}$ sucrose as possible) and transfer it into the new tubes.

5. Add $1 \mathrm{~mL}$ of $4{ }^{\circ} \mathrm{C}$ cold $\mathrm{ddH}_{2} \mathrm{O}$ and vortex.

6. Fill one tube with $4{ }^{\circ} \mathrm{C}$ cold $\mathrm{ddH}_{2} \mathrm{O}$ up to $0.5 \mathrm{~cm}$ below the tube edge and tare the other tubes with $\mathrm{ddH}_{2} \mathrm{O}$.

7. Centrifuge at $75,000 \times g$ for $15 \mathrm{~min}$ at $4{ }^{\circ} \mathrm{C}$ (rotor: TH64l at 24,400 rpm; acceleration 9, deceleration 9); always wait for vacuum.

1. Discard the supernatant and remove remaining fluid with paper tissue.

2. Add $1 \mathrm{~mL}$ cold $\mathrm{ddH}_{2} \mathrm{O}$ to each tube and resuspend the pellet (vortex).

3. Fill tubes with cold $\mathrm{ddH}_{2} \mathrm{O}$ up to $0.5 \mathrm{~cm}$ below tube edge and incubate $10 \mathrm{~min}$ on ice.

4. In the meantime tare the tubes with $\mathrm{ddH}_{2} \mathrm{O}$.

5. Centrifuge at $12,000 \times g$ for $15 \mathrm{~min}$ at $4{ }^{\circ} \mathrm{C}$ (rotor TH64l at $9800 \mathrm{rpm}$; acceleration 9, deceleration 9); always wait for vacuum. 
3.1.7 Second Osmotic Shock

3.1.8 Second Sucrose Density Gradient

3.1.9 Washing

$3.21 D-G e l$ Separation of Myelin for Proteome Analysis
1. Same procedure as for the first osmotic shock (see above).

2. During centrifugation, add protease inhibitors to $50 \mathrm{~mL}$ $0.32 \mathrm{M}$ sucrose (dissolve at $4{ }^{\circ} \mathrm{C}$, then keep on ice).

1. Place 6 new Beckman centrifuge tubes on ice.

2. Discard the supernatant and remove remaining fluid with paper tissue.

3. Add $1 \mathrm{~mL}$ cold $0.32 \mathrm{M}$ sucrose to each tube and resuspend the pellet (vortex).

4. Add additional $4 \mathrm{~mL}$ cold $0.32 \mathrm{M}$ sucrose.

5. Transfer $6 \mathrm{~mL}$ of cold $0.85 \mathrm{M}$ sucrose into each of the new tubes.

6. Carefully and slowly layer the crude myelin (in $0.32 \mathrm{M}$ sucrose) on top of the $0.85 \mathrm{M}$ sucrose.

7. Fill one tube with cold $0.32 \mathrm{M}$ sucrose up to $0.5 \mathrm{~cm}$ below tube edge and tare the other tubes with $0.32 \mathrm{M}$ sucrose to the same weight (max. difference $0.01 \mathrm{~g}$ ).

8. Centrifuge at $75,000 \times g$ for $30 \mathrm{~min}$ at $4{ }^{\circ} \mathrm{C}$ (rotor TH64l at $24400 \mathrm{rpm}$, acceleration 7, deceleration 7); always wait for vacuum.

9. During centrifugation, dilute $10 \times$ TBS to $1 \times$ TBS and add protease inhibitors (dissolve at $4{ }^{\circ} \mathrm{C}$, then keep on ice).

10. Purified myelin accumulates at the interface as a fluffy white cloud (Fig. 1).

1. Place 6 new Beckman Centrifuge tubes on ice.

2. Collect the interface with a Pasteur pipette and transfer it into the new tubes (on ice).

3. Fill one tube with cold $\mathrm{ddH}_{2} \mathrm{O}$ up to $0.5 \mathrm{~cm}$ below tube edge and tare the other tubes with $\mathrm{ddH}_{2} \mathrm{O}$.

4. Centrifuge at $75,000 \times g$ for $15 \mathrm{~min}$ at $4{ }^{\circ} \mathrm{C}$ (rotor TH64l at $24400 \mathrm{rpm}$; acceleration 9, deceleration 9); always wait for vacuum.

5. Discard the supernatant and remove remaining fluid with paper tissue.

6. Dissolve pellet in $200 \mu \mathrm{L}$ cold $1 \times$ TBS (supplemented with protease inhibitor).

7. Transfer myelin (in $1 \times$ TBS) to a new $1.5 \mathrm{~mL}$ Eppendorf tube and store at $-80{ }^{\circ} \mathrm{C}($ see Notes 6-9).

One-dimensional separation of myelin and immunoblot analysis (Fig. 2) can serve to test for the enrichment of myelin proteins and the diminishment of contaminants during the biochemical purification of myelin. When aiming to establish myelin protein 


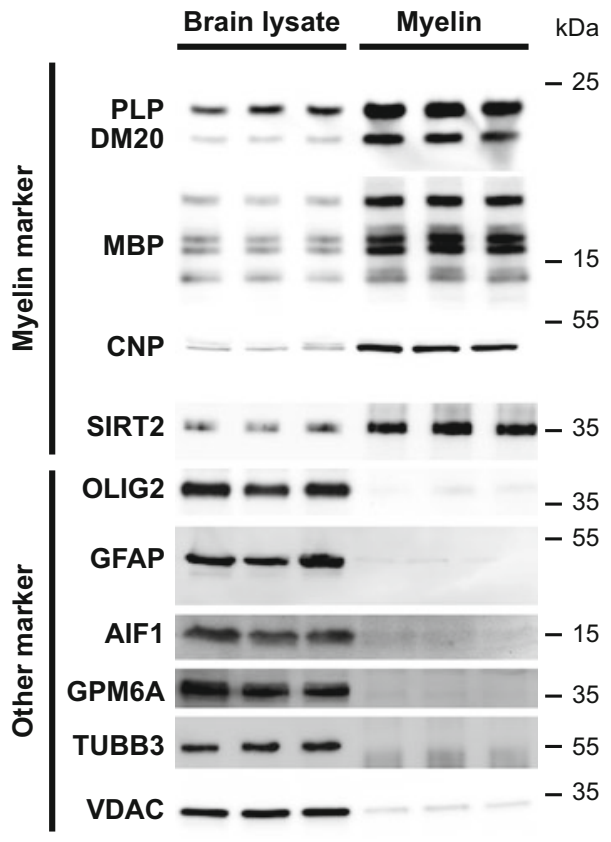

Fig. 2 Immunoblot illustrates that myelin proteins are enriched in purified myelin compared to brain lysate while markers for other cellular sources are diminished. The detected proteins localize to compact myelin (PLP/DM20, $\mathrm{MBP}$ ), non-compact myelin (CNP, SIRT2), the oligodendroglial nuclear/ cytoplasmic compartment (OLIG2), astrocytes (GFAP), microglia (AIF1/IBA1), the neuronal plasma membrane (GPM6A), axonal microtubules (TUBB3/TUJ1), and mitochondria (VDAC). The blot shows three biological replicates (male c57BI6/N mice at postnatal day 75); equal amounts of brain lysate and myelin were loaded. Figure modified from ref. [30]

inventories, the use of various complementary proteomic approaches (e.g., with or without pre-fractionation of undigested proteins) will provide the most comprehensive, yet nonquantitative compilation of the protein constituents. One-dimensional (1D)separation via SDS-PAGE (sodium dodecyl sulfate polyacrylamide gel electrophoresis) followed by in-gel tryptic digestion is possibly the simplest method to prepare myelin for the mass spectrometric identification of its proteins, including very hydrophobic transmembrane proteins (e.g., PLP, OSP/CLDN11) and proteins with extreme isoelectric points (e.g., MBP, MOBP). The comparatively low resolution provided by these gels is compensated by chromatographic separation of the proteolytic peptides prior to mass spectrometry (MS), an approach often referred to as "GeLC-MS."

For separation of purified myelin, we have mainly used precast Bis-Tris $4-12 \%$ gradient gels $(8 \times 8 \mathrm{~cm}, 1 \mathrm{~mm}$ gel thickness, NuPAGE, Thermo Fisher Scientific) according to the manufacturer's protocols. The running buffer containing 2-( $N$-Morpholino) 
A

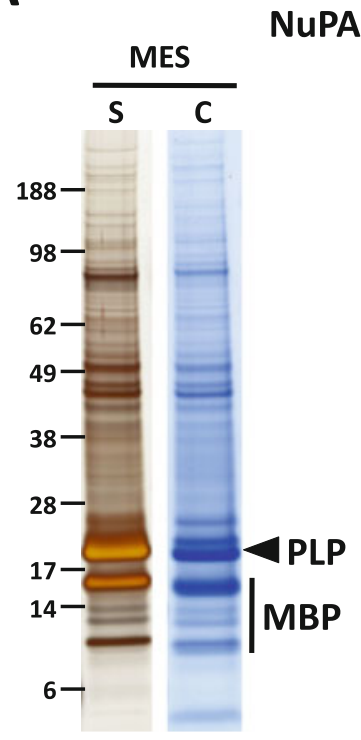

B

\section{TG PRiME}

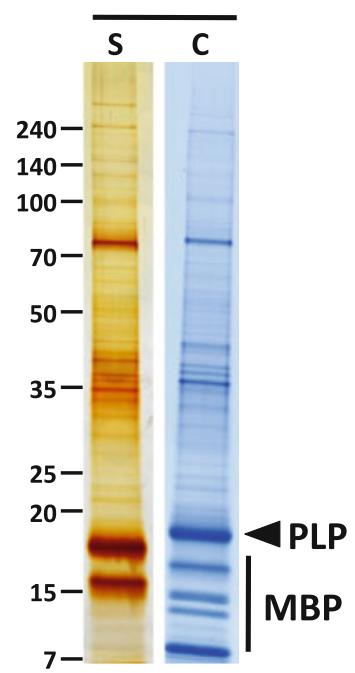

Fig. 3 Separation of purified CNS myelin in one-dimensional gels (see method 2). (a) Purified myelin was separated by SDS-PAGE using 4-12\% Bis-Tris gels (precast, NuPAGE). Different buffer systems enhance separation in the low (MES buffer) or high (MOPS buffer) molecular weight range. Proteins were visualized by silver staining (S; load $0.5 \mu \mathrm{g}$ per lane) or colloidal Coomassie (C; $5 \mu \mathrm{g}$ loaded). PLP proteolipid protein, MBP myelin basic protein. Molecular weight standard is given in $\mathrm{kDa}$. Figure modified from ref. [31] with permission. (b) More recently, we also use $8-16 \%$ Tris-glycine gels (precast, TG PRiME), yielding excellent separation of myelin

ethanesulfonic acid (MES) is recommended when aiming at good separation of myelin basic protein (MBP) and other small proteins, while the 3-( $N$-morpholino)propanesulfonic acid (MOPS) buffer system [45] enhances resolution in the molecular weight range above $25 \mathrm{kDa}$ (Fig. 3a). More recently, we have also used Tris-glycine $8-16 \%$ gradient gels $(7 \times 8 \mathrm{~cm}, 1 \mathrm{~mm}$ gel thickness, TG PRiME, Serva), newly available precast gels related to the commonly used Laemmli system. These gels provide coverage of a broad molecular weight range and a remarkably high resolution for large proteins (Fig. 3b).

For subsequent mass spectrometric protein identification, typically $5-10 \mu \mathrm{g}$ per lane of purified myelin is separated by 1D-SDS-PAGE. If a higher protein load is desired, it may be required to perform delipidation (see Subheadings 2.3.1 and 3.3.1) before loading, thereby preventing lipid-related distortion of separation particularly in the low molecular weight range (i.e., $<20 \mathrm{kDa}$ ).

To deplete soluble and membrane-associated proteins and thereby enrich membrane-spanning proteins, the myelin fraction may be subjected to consecutive high-salt and high-pH washing/ centrifugation cycles prior to loading on the gel as described previously [20]. 
3.2.2 Gel Staining

\subsection{D-IEF/SDS-}

PAGE Separation of Myelin for Proteome Analysis
For gel staining, we recommend colloidal Coomassie according to [46].

1. Fix gel with $40 \%(\mathrm{v} / \mathrm{v})$ ethanol, $10 \%(\mathrm{v} / \mathrm{v})$ acetic acid for at least l h.

2. Wash $3 \times 10$ min with $\mathrm{ddH}_{2} \mathrm{O}$.

3. Stain the gel in dye working solution at least overnight.

4. Transfer gel into a new box with $\mathrm{dd}_{2} \mathrm{O}$, wash until all Coomassie particles are removed (see Notes 10-13).

Two-dimensional (2D) separation of purified myelin provides highly reproducible protein maps $[20,47]$ and enables the resolution of different "proteoforms" (i.e., protein isoforms, splice variants, and posttranslationally modified species) of myelin proteins. Indeed, the combination of isoelectric focusing (IEF) as the first dimension with SDS-PAGE as the second dimension (2D-IEF/ SDS-PAGE; Fig. 4a) continues to be valuable for myelin proteome analysis despite limitations with respect to the underrepresentation of hydrophobic, transmembrane, and basic proteins. The separation of very basic proteins, or more generally the resolving power in the first dimension, can be improved by using longer IEF strips with wider $\mathrm{pH}$ gradients (Fig. 4b).
A

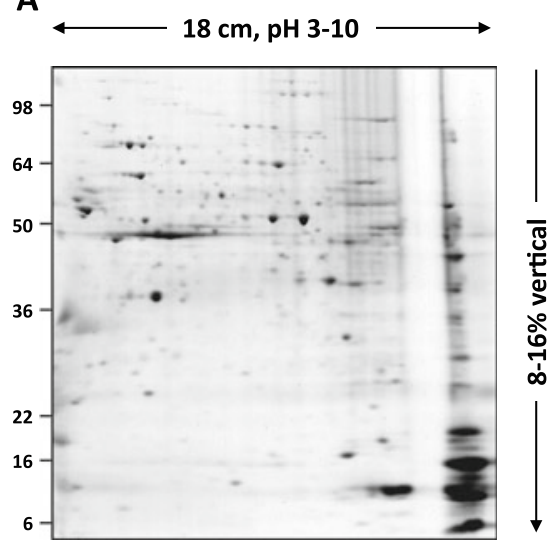

B

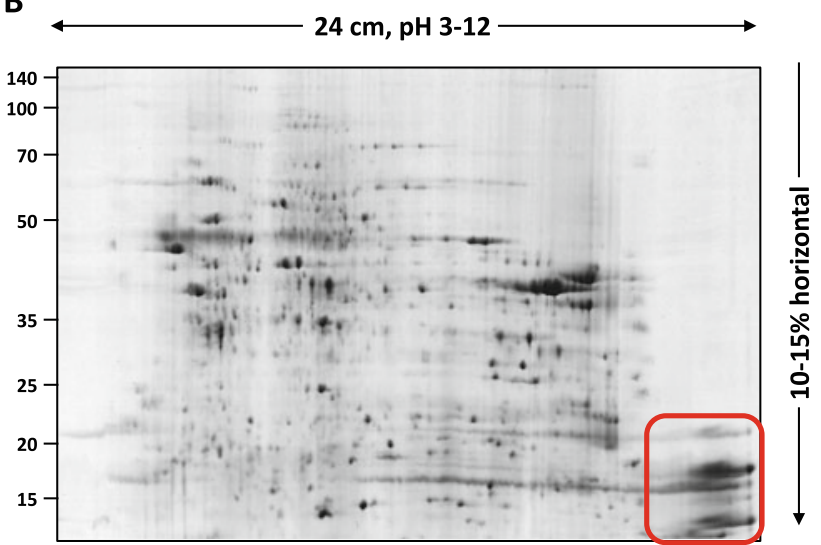

Fig. 4 Myelin proteome maps based on two-dimensional gels (see method 3). (a) Purified myelin was separated two-dimensionally using isoelectric focusing (IEF) in a nonlinear pH-gradient (pH 3-10, $18 \mathrm{~cm}$ gel) as the first and SDS-PAGE (self-cast $8-16 \%$ gel, vertically run) as the second dimension. Proteins were stained using colloidal Coomassie and identified by MALDI-TOF-MS. Molecular weight standard is given in $\mathrm{kDa}$. Figure modified from ref. [20]. (b) More recently, we have changed the separation conditions to a pH 3-12 gradient ( $24 \mathrm{~cm}$ gel) as the first and horizontally run $10-15 \%$ precast gels as the second dimension, thereby gaining improved separation of basic proteins. We note that proteoforms of myelin basic protein (MBP, encircled in red) are still hardly resolvable due to their extreme basicity. Yet, moving MBP out of the more populated part of the gel allows the detection of previously masked spots 
3.3.1 Delipidation/ Precipitation/Solubilization
Prior to 2D-IEF/SDS-PAGE, purified myelin is first delipidated and precipitated with methanol/chloroform according to [48], as lipids and salts compromise the resolution during IEF. The solubility of hydrophobic and glycosylphosphatidylinositol (GPI)anchored myelin proteins is greatly improved by the zwitterionic detergent amidosulfobetaine ASB-14 compared to the commonly used 3-[(3-cholamidopropyl)-dimethylammonio]-1-propanesulfonate (CHAPS) [49], thereby enhancing their resolution by 2D-IEF/SDS-PAGE.

1. Thaw myelin sample on ice (the precipitation procedure itself is performed at room temperature (RT)).

2. Transfer $150 \mu \mathrm{L}$ of purified myelin (typical protein concentration $\sim 4 \mu \mathrm{g} / \mu \mathrm{L}$ ) into a $1.5 \mathrm{~mL}$ tube (preferably Eppendorf SafeLock) (see Note 14).

3. Add $600 \mu \mathrm{L}$ methanol; vortex.

4. Add $300 \mu \mathrm{L}$ chloroform; vortex.

5. Add $450 \mu \mathrm{L}$ ddH ${ }_{2} \mathrm{O}$.

6. Centrifuge at $9000 \times \mathfrak{g}$ for $1 \mathrm{~min}$ (proteins accumulate at the interface).

7. Discard upper phase by pipetting.

8. Add $450 \mu \mathrm{L}$ methanol and vortex.

9. Centrifuge at $16,100 \times g$ for $5 \mathrm{~min}$ to pellet precipitated proteins.

10. Discard supernatant by pipetting.

11. Dry pellet (use nitrogen stream; do not dry entirely).

12. Add $50 \mu \mathrm{L}$ homogenization buffer and solubilize carefully (ultrasonic bath or freezing/thawing cycles help to solubilize the pellet; no vortexing to prevent foaming); prevent from heating up above $37^{\circ} \mathrm{C}$ to avoid protein carbamylation (see Note 15).

13. Centrifuge at $10,000 \times g$ for $2 \mathrm{~min}$.

14. Transfer supernatant into a new $1.5 \mathrm{~mL}$ tube.

15. Determine protein concentration by 2D-Quant Kit (GE Healthcare) (see Note 16).

Here, we describe a novel protocol for focusing myelin proteins on $24 \mathrm{~cm}$ immobilized $\mathrm{pH}$-gradient (IPG) strips of nonlinear $\mathrm{pH} 3-12$. For our previous protocol employing $18 \mathrm{~cm}$ IPG-strips of nonlinear $\mathrm{pH} 3-10$ the reader is referred to a previous methods article [50].

1. Take the volume equivalent of $300 \mu \mathrm{g}$ protein per IPG-strip and mix with the same volume rehydration buffer I.

2. Sonicate for $2 \mathrm{~min}$, shake gently $(700 \mathrm{rpm})$ for $15 \mathrm{~min}$ at RT. 
3.3.3 SDS-PAGE

\subsection{Filter-Aided Sample Preparation (FASP) for Gel-Free Myelin Proteome Analysis}

3. Fill up to $450 \mu \mathrm{L}$ with rehydration buffer II (see Note 17).

4. Sonicate for $2 \mathrm{~min}$, shake gently $(700 \mathrm{rpm})$ for $30 \mathrm{~min}$ at RT.

5. Centrifuge $10,000 \times g$ for $1 \mathrm{~min}$.

6. Transfer $450 \mu \mathrm{L}$ of supernatant to focusing tray, apply IPG-strip facing the gel-side down. Let the strip re-swell for 15 min and cover slot with mineral oil.

7. After $12 \mathrm{~h}$ active rehydration at $50 \mathrm{~V}\left(70 \mu \mathrm{A}\right.$ per strip, $\left.20{ }^{\circ} \mathrm{C}\right)$, apply water-wetted paper pads to both electrodes (the cathode pad should be soaking to compensate water flow from cathode to anode in highly basic $\mathrm{pH}$-gradients).

Focus for about $40 \mathrm{kVh}\left(125 \mu \mathrm{A}\right.$ per strip, $\left.20^{\circ} \mathrm{C}\right)$ by a ramped two-step protocol $(0-8000 \mathrm{~V} / 1 \mathrm{~h}, 8000 \mathrm{~V} / 4 \mathrm{~h})$ on an IPGphor (GE Healthcare) or a Protean il2 (BioRad) IEF system. The latter has the advantage that the program of choice is regulated for each strip individually.

Here, we describe the use of precast gels polymerized on a non-fluorescent backing film, of which up to four can be run simultaneously in horizontal electrophoresis chambers (Serva HPE system). The major advantage of this high-performance electrophoresis system is the efficient cooling of the horizontal gels during the runs, which, together with other technical refinements, allows excellent reproducibility, spot resolution and detection sensitivity [51]. For our previous protocol employing self-cast $18 \times 20 \mathrm{~cm}$ gels for the second dimension the reader is referred to a previous methods article [50].

We use 10-15\% acrylamide gradient gels $(25.5 \times 20 \mathrm{~cm}$, gel thickness $0.65 \mathrm{~mm}$ ) according to the manufacturer's manual (Serva HPE system) and in the following only list our adaptations for the separation of myelin.

1. Increase the SDS content of the equilibration solution to $6 \%$.

2. Use $6 \mathrm{~mL}$ cooling contact fluid (at least for the first generation HPE tower).

3. Run final step of electrophoresis 60 min longer ( see Notes 18 and 19).

The outstanding sensitivity of current mass spectrometers necessitates careful consideration of sample preparation. In particular, it is crucial that substances are efficiently removed (or at least diminished) that may interfere with chromatographic separation or electrospray ionization. Moreover, particle-free samples are required when direct injection setups without trapping columns are used to provide higher chromatographic separation [52].

In our previous studies $[4,34,47]$ we have successfully subjected myelin to tryptic in-solution digest in the presence of the 
acid-labile surfactant RapiGest (Waters) (for protocols see refs. $[34,50])$. Indeed, this method has facilitated sufficiently robust solubilization and unfolding of proteins. Yet, in our current view the particular requirements of myelin samples are met even better by filter-aided sample preparation (FASP) [53]. FASP allows the depletion of soluble low molecular weight compounds (including detergents) from a complex protein mixture by washing it with urea buffer in an ultrafiltration device, which is followed by buffer exchange, direct on-filter digestion, and recovery of the proteolytic peptides by filtration (for overview see Fig. 5). The ultrafiltration devices are designed as spin columns and typically

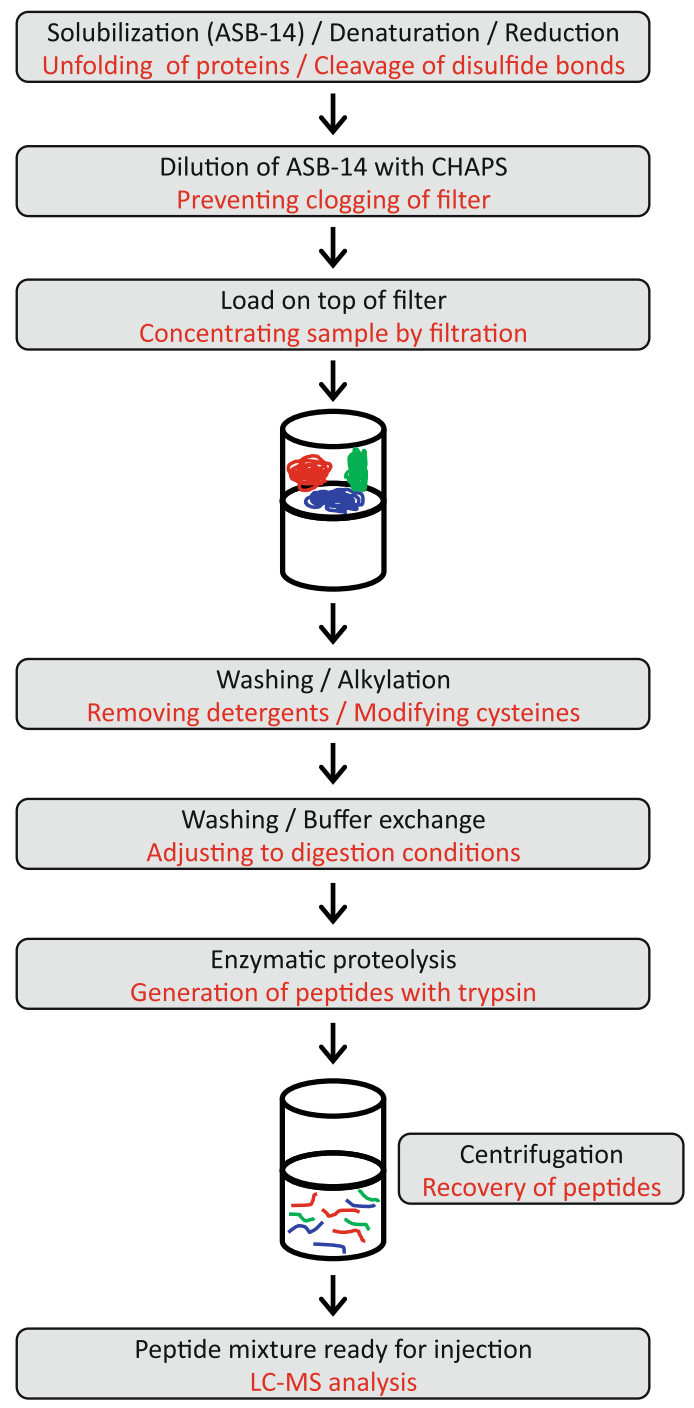

Fig. 5 Schematic overview of filter-aided sample preparation (FASP). For details see method 4 
3.4.1 Procedure operated by centrifugation. However, reasoning that vacuumdriven removal of liquids can enable the automation of FASP we have implemented the procedure into a liquid handling workstation, the customized hardware and software components of which will be described elsewhere. The procedure itself is adapted from a previously reported manual protocol [52]. We consider FASP automation as important toward even higher reproducibility of sample preparation that is essential for quantitative label-free proteome profiling.

1. Solubilize and denature $10 \mu \mathrm{g}$ of purified myelin in $150 \mu \mathrm{L}$ Lysis buffer containing 1\% (w/v) ASB-14 and 10 mM DTT, sonicate for $5 \mathrm{~min}$, incubate for $30 \mathrm{~min}$ at $37^{\circ} \mathrm{C}$ while shaking.

2. Dilute sample with $1500 \mu \mathrm{L}$ Lysis buffer containing $2 \%(\mathrm{w} / \mathrm{v})$ CHAPS to reduce ASB- 14 concentration to below $0.1 \%(\mathrm{w} / \mathrm{v})$.

3. In parallel, rinse the filter unit first with $100 \mu \mathrm{L}$ of $1 \%(\mathrm{v} / \mathrm{v})$ formic acid (FA) and then with $200 \mu \mathrm{L} 8 \mathrm{M}$ urea buffer/ $10 \mathrm{mM}$ DTT. A centrifuge $(11,000 \times g$, RT $)$ or a vacuum manifold $(\Delta 600 \mathrm{mbar}, \mathrm{RT})$ can be used in this and all following steps unless noted otherwise. In the following protocol, centrifugation/application of vacuum is referred to as "liquid removal."

4. Transfer $220 \mu \mathrm{L}$ of myelin to the filter unit, remove buffer on top of the filter by liquid removal. Repeat until all volume is applied to the filter unit. Always sonicate the solubilized sample for $5 \mathrm{~min}$ before transferring an aliquot onto the filter.

5. Wash $2 \times$ with $200 \mu \mathrm{L}$ urea buffer/10 mM DTT to deplete detergents by liquid removal.

6. Optional: Pause the procedure overnight. Cover the filter membrane with $100 \mu \mathrm{L}$ urea buffer/10 mM DTT, cap the filter units and store in wet chamber at RT. Liquid removal is required before proceeding to the next step.

7. Alkylate cysteine residues by addition of $100 \mu \mathrm{L} 45 \mathrm{mM}$ iodoacetamide in urea buffer (prepare freshly just before use from $450 \mathrm{mM}$ stock solution in water), incubate $20 \mathrm{~min}$ at RT in the dark, followed by liquid removal.

8. Wash $2 \times$ with $200 \mu \mathrm{L}$ urea buffer/10 mM DTT to quench excessive iodoacetamide, followed by liquid removal.

9. Wash $3 \times$ with 200,300 , and $450 \mu \mathrm{L} 50 \mathrm{mM}$ ammonium bicarbonate $/ 10 \%(\mathrm{v} / \mathrm{v})$ acetonitrile for buffer exchange, followed by liquid removal.

10. Place filter unit onto centrifugation tube.

11. Wash $3 \times$ with $200 \mu \mathrm{L} 50 \mathrm{mM}$ ammonium bicarbonate/10\% $(\mathrm{v} / \mathrm{v})$ acetonitrile, followed by liquid removal. Centrifuge $30 \mathrm{~min}$ at $10,000 \times g(\mathrm{RT})$. 
12. Place filter unit onto new centrifugation tube.

13. Add $40 \mu \mathrm{L}$ of trypsin working solution $(0.01 \mu \mathrm{g} / \mu \mathrm{L})$ in $50 \mathrm{mM}$ ammonium bicarbonate/ $10 \%$ acetonitrile to the filter, shake once gently (manually) and digest overnight at $37^{\circ} \mathrm{C}$ in a wet chamber.

14. Centrifuge the filter for $30 \mathrm{~min}$ at $11,000 \times g(\mathrm{RT})$ and collect the flow-through.

15. Add $40 \mu \mathrm{L} 50 \mathrm{mM}$ ammonium bicarbonate in water, centrifuge for $30 \mathrm{~min}$ at $11,000 \times g(\mathrm{RT})$ and collect the flow-trough into the same tube.

16. Add $40 \mu \mathrm{L} 1 \%(\mathrm{v} / \mathrm{v})$ trifluoroacetic acid (TFA) in water, centrifuge for $30 \mathrm{~min}$ at $11,000 \times g(\mathrm{RT})$ and collect the flow-trough into the same tube.

17. Combined flow-through is transfered to $1.5 \mathrm{~mL}$ low proteinbinding tubes (e.g., Eppendorf LoBind or equivalent), document the volume.

18. Mix $2 \mu \mathrm{L}$ Yeast Enolase 1 digestion standard or Hi3 EColi standard (Waters) $(100 \mathrm{fmol} / \mu \mathrm{L})$ with $20 \mu \mathrm{L}$ of sample in a glass autosampler vial for LC-MS analysis (see Notes 20-24).

3.5 Gel-Free Myelin Proteome Analysis and Mass Spectrometric Quantification of a Myelin Protein Using CNP as an Example
For myelin proteome analysis, gel-free ("shotgun") approaches allow circumventing many of the limits of gel-based approaches, especially those of $2 \mathrm{D}$-IEF/SDS-PAGE (see above). The replacement of gel-based separation of entire proteins by their tryptic cleavage and subsequent separation of the resulting peptides via high resolution liquid chromatography (LC) before interfacing with mass spectrometry (LC-MS) goes at the expense of information about protein size and charge. This is a disadvantage when analyzing "proteoforms," i.e., protein isoforms, splice variants, or posttranslationally modified proteins. However, LC-MS is particularly well suited for quantitative and differential analyses of the myelin proteome with its many extraordinarily basic or hydrophobic proteins and its exceptional range of several orders of magnitude of protein abundance. Indeed, LC-MS enables the label-free quantification of proteins in complex samples such as myelin with the required dynamic range, yet it implements no bias against particular protein classes. Finally, only low amounts of starting material are required, about 100th compared to 2D-IEF/SDSPAGE.

We note that the particular procedure of myelin proteome analysis will greatly depend on the locally available mass spectrometer and associated data acquisition and quantification method. For our investigations, we have decided for separation using nanoscale ultraperformance liquid chromatography (nanoUPLC) with quadrupole time of flight (QTOF)-mass spectrometers that allow a dataindependent acquisition workflow with alternating low-energy and 
elevated-energy scans (e.g., QTOF-Premier or Synapt G2S, Waters). We refer the reader to previous articles for an overview about data-independent acquisition methods [54] or for a detailed protocol [52]. To determine the absolute abundance of myelin proteins, we utilized the data post-processing software ISO-Quant [55], which quantifies the validated mass spectra of the three most abundant peptides per protein according to the TOP3 method [56]. To compare the abundance of a myelin protein between two states (e.g., between mutant and control mice), its relative abundance was considered changed if significant according to two-tailed t-test and exceeding a threshold of $25 \%$. This approach has enabled robust and reliable differential analysis of the entire myelin proteome in various mouse models of myelinrelated pathology [34].

To exemplify the power of gel-free mass spectrometry for the differential quantification of myelin proteins, we have assessed the abundance of cyclic nucleotide phosphodiesterase (CNP) $[57,58]$, the third-most abundant CNS myelin protein [4]. Heterozygous $\mathrm{Cnp} \mathrm{p}^{+/-}$mice display a catatonia-depression syndrome upon aging [59]; yet their myelin appears morphologically normal. Cnp $p^{+/-}$ mice provide a defined model in which the halved gene dosage should theoretically lead to a halved abundance of CNP in myelin. Indeed, when using the workflow outlined above, the abundance of $\mathrm{CNP}$ in myelin purified from $\mathrm{Cnp}^{+/-}$mice compared to wild-type littermates is $50.7 \%( \pm 0.4 \%)$. The remarkable exactness of the quantification and the excellent sample-to-sample reproducibility (see Fig. 6) allows high confidence in unexpected findings yielded by differential myelin proteome analyses, notwithstanding that relevant-appearing results require validation by independent methods.

In conclusion, the method to purify myelin from nervous tissue has changed only moderately since the 1960s and 1970s, reflecting its efficiency and the excellent degree of myelin membrane enrichment that can be gained reliably and reproducibly. More recently, it was possible to combine myelin purification with modern "omics"-techniques to systematically determine molecular composition at the level of mRNA [30], lipids [29], and proteins. With respect to lipids, carbohydrates, and posttranslational modifications, their capabilities are not yet exploited to their full extent. However, myelin proteome analysis has proven a valuable resource for myelin research, as it has facilitated selecting proteins for functional investigations in mutant mice, revising the abundance of myelin proteins $[4,47]$, calculating molar ratios [60-62], analyzing models of myelin-related disorders [20, 39, 47, 63-65], discovering disease-causing genes [66], and identifying a novel molecular scaffold in the myelin sheath [34]. We believe that systematic approaches to myelin involving "omics"techniques hold great promise for improving our understanding 
A

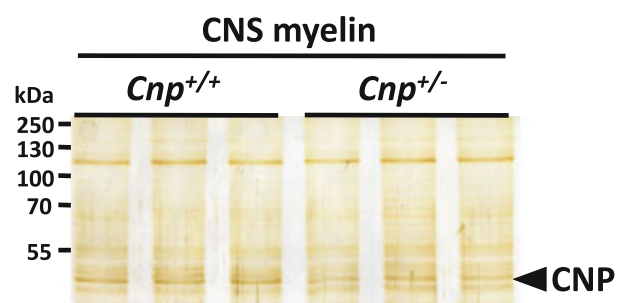

B

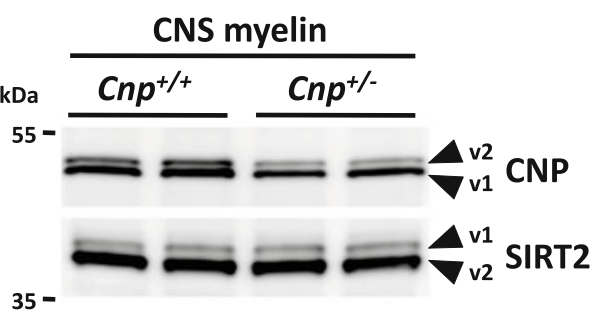

$35-$

$25-$

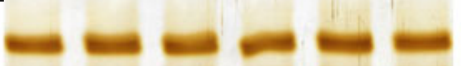

$15-$

$C_{\text {PPM }}$

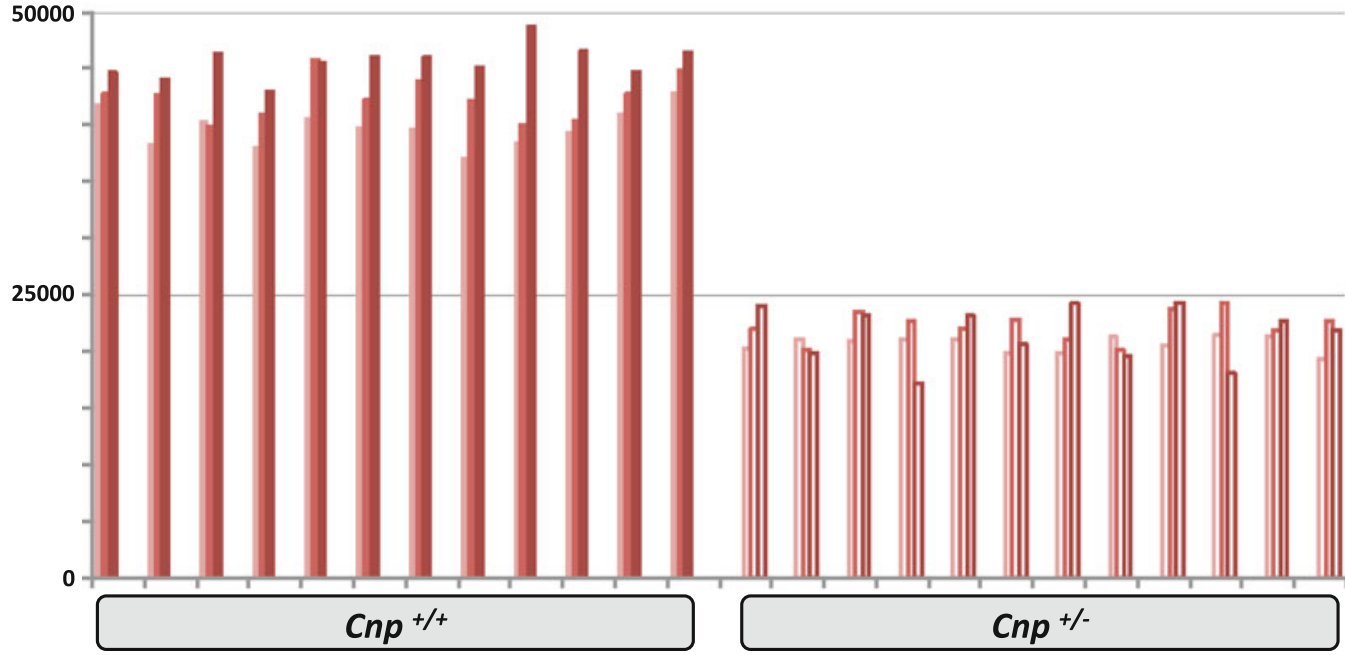

D

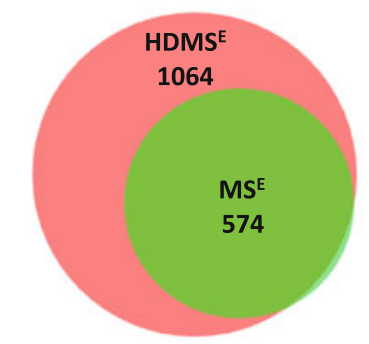

HDMS $^{\mathrm{E}}$ VS. MSE
E

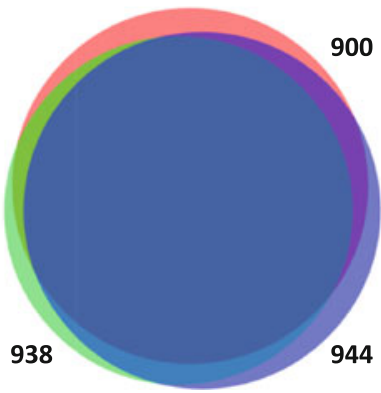

HDMS $^{E}$

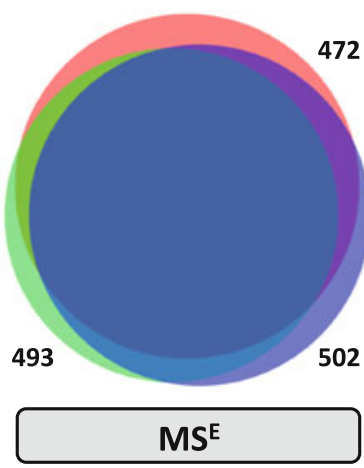

472

Fig. 6 Quantification of myelin proteins by label-free mass spectrometry using CNP as an example. $(a, b)$ One-dimensional SDS-PAGE separation and silver staining (a) or immunoblotting (b) of myelin purified from mouse brains at P75 indicate that the abundance of CNP in myelin is reduced in heterozygous $\mathrm{Cnp}^{+/-}$mice compared to wild-type littermates. Sirtuin 2 (SIRT2) served as a loading control. CNP cyclic nucleotide 
of the development, structure and function of the axon/myelinunit in the context of the healthy and the pathological nervous system.

\section{Notes}

1. Optional: When dissecting the tissue earlier, store at $-80^{\circ} \mathrm{C}$ or keep frozen on dry ice until just before homogenization.

2. Optional: Animals may be transcardially perfused with physiological salt solution (HBSS, PBS), thereby clearing capillaries and reducing contamination of the myelin fraction with proteins derived from blood.

3. Optional: Store $400 \mu \mathrm{L}$ of the homogenate for later use $\left(-80^{\circ} \mathrm{C}\right)$, e.g., for control by immunoblot analysis as exemplified in Fig. 2.

4. Do not add the homogenate drop by drop; best phase separation is achieved when the homogenate flows down slowly along the tube wall. The tube is placed vertically on ice; the pipette is tilted by $45^{\circ}$.

5. The tubes have to be weighed with adaptor and lid. Dry the centrifuge tubes before placing them into the adaptor. Dry the adaptors before placing them in the rotor.

6. From half a mouse brain, about $600 \mu \mathrm{g}$ of purified myelin can be expected. For measuring protein concentrations, we recommend a Lowry assay (e.g., Biorad DC Protein Assay) or the precipitation-based assay kits 2-D Quant (GE Healthcare) or SingleQuant (Serva). Myelin should be well homogenized, e.g., using a Teflon pestle that fits exactly with $1.5 \mathrm{~mL}$ Eppendorf tubes (e.g., Thomas Scientific).

Fig. 6 (continued) phosphodiesterase. Arrowheads point at protein isoforms. (c) Differential myelin proteome analysis quantifies the abundance of CNP in myelin purified from heterozygous $\mathrm{Cnp}^{+/}$mice as $50.7 \%$ $( \pm 0.4 \%)$ compared to wild-type littermates. The bar graph shows individual data points for three independent experiments with three biological replicates per genotype and four technical replicates per biological replicate. For details, see method 5. PPM parts per million. (d) Venn diagram comparing the number of proteins identified in myelin by $\mathrm{MS}^{\mathrm{E}}$ (as used for quantification in Fig. 6c) with those identified by high-definition MS ${ }^{\mathrm{E}}$ $\left(\mathrm{HDMS}^{\mathrm{E}}\right.$ ). The higher proteome depth of $\mathrm{HDMS}^{\mathrm{E}}$ owing to the ion mobility option, which may be considered as a gas phase electrophoresis-like device that equips modern mass spectrometers with an additional level of peptide separation. As this compresses the dynamic range of quantification, highly abundant proteins such as $\mathrm{PLP}, \mathrm{MBP}$, and CNP are more reliably quantified by $\mathrm{MS}^{\mathrm{E}}$ (i.e., without ion mobility separation) at the cost of the number of identified proteins. (e) Venn diagram comparing the proteins identified in three biological replicates of myelin by $\mathrm{HDMS}^{\mathrm{E}}$ (left image) or $\mathrm{MS}^{\mathrm{E}}$ (right image). Note that both approaches allow excellent sample-tosample reproducibility 
7. Myelin samples to be compared in one experiment should be purified in parallel, i.e., in one rotor run.

8. Quality control may include electron microscopy [20] and immunoblot (Fig. 2).

9. Myelin purified according to this protocol can be used for protein and lipid analyses, RNA extraction, enzymatic assays, electron microscopy, and other applications.

Optional: When posttranslational modifications are to be analyzed, the supplementation of solutions with respective inhibitors may be beneficial. For example, add phosphatase inhibitors (e.g., PhosStop cocktail tablets, Roche) or deacetylase inhibitors (10 mM Nicotinamide (Sigma-Aldrich), $0.5 \mu \mathrm{M}$ Trichostatin A (Sigma-Aldrich)) to $0.32 \mathrm{M}$ sucrose and $1 \times$ TBS.

If aiming to isolate RNA from purified myelin [30], work under RNAse-free conditions is advantageous. Clean the bench, all materials, skull, and brain with RNAse AWAY (Sigma-Aldrich); use RNAse-free sucrose (e.g., Sigma-Aldrich) and DEPC-treated $\mathrm{ddH}_{2} \mathrm{O}$; after the last washing step dissolve myelin in QIAzol (Qiagen) instead of TBS; wear a mask and gloves at all times.

Subfractions of low, medium, and high density can be isolated from purified myelin [67-71]. Note that it is speculative if these subfractions correspond to distinct subcompartments of myelin.

Aiming to further purify the myelin fraction, purified myelin was subjected to two additional osmotic shocks and a third ultracentrifugation step using a "floating-up" protocol [67]. For the floating-up gradient, myelin was resuspended in $0.83 \mathrm{M}$ sucrose and overlayered with $0.3 \mathrm{M}$ sucrose; during ultracentrifugation myelin accumulated at the interface. Note that in our experience this procedure does not yield better purity but results in considerable material loss and should thus be omitted.

The purification of peripheral myelin requires different sucrose concentrations $(0.27 \mathrm{M}$ and $0.83 \mathrm{M}$ sucrose $)$ and only one gradient ultracentrifugation step [21, 47, 67]. A yield of up to $200 \mu \mathrm{g}$ of purified myelin can be expected when pooling 30 sciatic nerves from 15 adult mice. Note that the achievable factor of enrichment is lower compared to central myelin.

Myelin has been purified from other species $([72,73]$ and references therein), including rats $[74,75]$, humans $[29,32$, 76], clawed frogs [5], and zebrafish [77-79]. Note that sucrose concentrations may require adaptation if the density of myelin in a species differs from that in mice. 
10. Only glass containers or plastic containers specified for gel staining should be used because low-quality plastic may emit substances that impede mass spectrometric identification.

11. Stained gels can be imaged using a near-infrared fluorescence scanner $[80,81]$ or a conventional flatbed scanner.

12. For mass spectrometric protein identification, manually cut out individual bands immediately after gel staining. Alternatively, excise entire gel lanes with a custom-made punching tool, resulting in 24 uniformly sized gel bands that can be subjected to automated in-gel digestion in microplate format [82]. Store gel bands or slices in adequate vials or microplates at $-20{ }^{\circ} \mathrm{C}$ until further processed.

13. Wearing gloves and a hair net during these procedures minimizes the contamination of the samples with human keratins.

14. $150 \mu \mathrm{L}$ is the maximal input volume for $1.5 \mathrm{~mL}$ tubes. If upscaling is desired, we recommend $5 \mathrm{~mL}$ Eppendorf SafeLock tubes and the corresponding fixed-angle rotor as the procedure appears to require the specific tube geometry for proper function

15. Optional: These buffer conditions also allow labeling with fluorescent dyes for quantitative comparison of proteomes by 2D difference gel electrophoresis (2D-DIGE). See refs. $[83,84]$ for protocols, as well as refs. [20,47] for application to central and peripheral myelin, respectively.

16. For myelin delipidation/precipitation, expect protein loss of up to $50 \%$.

17. This is a typical buffer composition for anodal cup-loading, which is commonly favored for focusing in highly basic gradients. Importantly, conventional cup-loading in our hands was incompatible with myelin, likely due to aggregation. However, the addition of DeStreak diminishes horizontal streaking also after rehydration loading, at least for separation of myelin proteins in broad $\mathrm{pH}$-gradients of up to $\mathrm{pH} 12$.

18. After gel staining (see Subheadings 2.2.2 and 3.2.2), cylindric gel spots are excised manually and subjected to automated in-gel digestion in microplate format, followed by analysis on a MALDI-TOF mass spectrometer [85].

19. As the improved coverage of membrane proteins comes at the cost of resolution, we currently see no major advantages in replacing IEF as the first dimension by size-dependent separation in presence of the cationic detergent 16-BAC (16-benzyldimethyl- $n$-hexadecylammonium chloride). For a detailed protocol of subjecting CNS myelin to 2D-16-BAC/SDSPAGE we refer the reader to a previous methods article [50]. 
20. Pre-solubilization of myelin with ASB-14 under reducing conditions is crucial to increase accessibility of proteins for subsequent alkylation and enzymatic proteolysis. ASB-14 instead of CHAPS was chosen based on prior work [49] and our subsequent positive experience from 2D-IEF/SDS-PAGE (see Subheading 3.3). Although used in the original FASP protocol [53], we omit the anionic detergent SDS because potential remains of SDS (but not of the zwitterionic detergents ASB-14 and CHAPS) necessitate sample cleanup prior to injection to protect chromatography columns. Dilution with CHAPS buffer prevents clogging of the filter membrane.

21. Centrifugation is preferred when quantitative liquid removal is desired, as it cannot be entirely excluded that liquid remains within the membrane support in the bottom part of the filter unit after vacuum application.

22. Tryptic digestion in the presence of $10 \%$ acetonitrile facilitates the solubility of proteins after removal of urea and of nascent hydrophobic peptides.

23. Stepwise recovery of the tryptic peptides under different $\mathrm{pH}$ conditions is intended to increase peptide yield and leads to a sample that is ready to inject without further concentration or cleanup.

24. Centrifugation/vacuum application times may vary considerably depending on the protein input. A typical timing for FASP digestion of myelin is around $24 \mathrm{~h}$ with manual centrifugation being somewhat faster than automated vacuum-driven operation. However, considering that the latter is largely a walk-away process, its robustness and reproducibility clearly compensate the higher time need.

\section{Acknowledgment}

We thank K.-A. Nave for discussions and financial support made possible by an European Research Council (ERC) Advanced Grant.

\section{References}

1. Folch J, Ascoli I, Lees M, Meath JA, Le BN (1951) Preparation of lipide extracts from brain tissue. J Biol Chem 191(2):833-841

2. Folch J, Lees M (1951) Proteolipides, a new type of tissue lipoproteins; their isolation from brain. J Biol Chem 191(2):807-817

3. Lees MB (1998) A history of proteolipids: a personal memoir. Neurochem Res 23 (3):261-271
4. Jahn O, Tenzer S, Werner HB (2009) Myelin proteomics: molecular anatomy of an insulating sheath. Mol Neurobiol 40(1):55-72

5. Mobius W, Patzig J, Nave KA, Werner HB (2008) Phylogeny of proteolipid proteins: divergence, constraints, and the evolution of novel functions in myelination and neuroprotection. Neuron Glia Biol 4(2):111-127. https://doi. org/10.1017/S1740925X0900009X 
6. de Monasterio-Schrader P, Patzig J, Mobius W, Barrette B, Wagner TL, Kusch K, Edgar JM, Brophy PJ, Werner HB (2013) Uncoupling of neuroinflammation from axonal degeneration in mice lacking the myelin protein tetraspanin2. Glia 61(11):1832-1847. https://doi.org/ $10.1002 /$ glia.22561

7. Brophy PJ, Horvath LI, Marsh D (1984) Stoichiometry and specificity of lipid-protein interaction with myelin proteolipid protein studied by spin-label electron spin resonance. Biochemistry 23(5):860-865

8. Yamaguchi $Y$, Ikenaka $K$, Niinobe $M$, Yamada H, Mikoshiba K (1996) Myelin proteolipid protein (PLP), but not DM-20, is an inositol hexakisphosphate-binding protein. J Biol Chem 271(44):27838-27846

9. Simons M, Kramer EM, Thiele C, Stoffel W, Trotter J (2000) Assembly of myelin by association of proteolipid protein with cholesteroland galactosylceramide-rich membrane domains. J Cell Biol 151(1):143-154

10. Kramer-Albers EM, Gehrig-Burger K, Thiele C, Trotter J, Nave KA (2006) Perturbed interactions of mutant proteolipid protein/ DM20 with cholesterol and lipid rafts in oligodendroglia: implications for dysmyelination in spastic paraplegia. J Neurosci 26 (45):11743-11752. https://doi.org/10. 1523/JNEUROSCI.3581-06.2006

11. Ozgen H, Schrimpf W, Hendrix J, de Jonge JC, Lamb DC, Hoekstra D, Kahya N, Baron W (2014) The lateral membrane organization and dynamics of myelin proteins PLP and MBP are dictated by distinct galactolipids and the extracellular matrix. PLoS One 9(7): el01834. https://doi.org/10.1371/journal. pone.0101834

12. Werner HB, Kramer-Albers EM, Strenzke N, Saher G, Tenzer S, Ohno-Iwashita Y, De Monasterio-Schrader P, Mobius W, Moser T, Griffiths IR, Nave KA (2013) A critical role for the cholesterol-associated proteolipids PLP and M6B in myelination of the central nervous system. Glia 61(4):567-586. https://doi.org/ $10.1002 /$ glia.22456

13. Mandel P, Borkowski T, Harth S, Mardell R (1961) Incorporation of $32 \mathrm{P}$ in ribonucleic acid of subcellular fractions of various regions of the rat central nervous system. J Neurochem 8:126-138

14. Eichberg J, Whittaker VP, Dawson RM (1964) Distribution of lipids in subcellular particles of Guinea-pig brain. Biochem J 92(1):91-100

15. Korey SR, Orchen M, Brotz M (1958) Studies of white matter. I. Chemical constitution and respiration of neuroglial and myelin enriched fractions of white matter. J Neuropathol Exp Neurol 17(3):430-438

16. August C, Davison AN, Maurice-Williams F (1961) Phospholipid metabolism in nervous tissue. 4. Incorporation of P32 into the lipids of subcellular fractions of the brain. Biochem J 81:8-12

17. Autilio LA, Norton WT, Terry RD (1964) The preparation and some properties of purified myelin from the central nervous system. J Neurochem 11:17-27

18. Norton WT, Poduslo SE (1973) Myelination in rat brain: method of myelin isolation. J Neurochem 21(4):749-757

19. Haley JE, Samuels FG, Ledeen RW (1981) Study of myelin purity in relation to axonal contaminants. Cell Mol Neurobiol 1 (2):175-187

20. Werner HB, Kuhlmann K, Shen S, Uecker M, Schardt A, Dimova K, Orfaniotou F, Dhaunchak A, Brinkmann BG, Mobius W, Guarente L, Casaccia-Bonnefil P, Jahn O, Nave KA (2007) Proteolipid protein is required for transport of sirtuin 2 into $\mathrm{CNS}$ myelin. J Neurosci 27(29):7717-7730. https://doi.org/10.1523/JNEUROSCI. 1254-07.2007

21. Wiggins RC, Fuller GN (1981) Analysis of distribution of rat sciatic nerve protein among soluble, insoluble, and myelin subfraction. Neurochem Res 6(6):719-727

22. Gent WL, Gregson NA, Gammack DB, Raper JH (1964) The lipid-protein unit in myelin. Nature 204:553-555

23. Wolfgram F, Kotorii K (1968) The composition of the myelin proteins of the central nervous system. J Neurochem 15(11):1281-1290

24. Morell P, Greenfield S, Costantino-Ceccarini E, Wisniewski H (1972) Changes in the protein composition of mouse brain myelin during development. J Neurochem 19 (11):2545-2554

25. Ewald A, Kühne W (1874-1877) Ueber einen neuen Bestandtheil des Nervensystems. Verhandlungen des NaturhistorischMedizinischen Vereins zu Heidelberg $1: 457-464$

26. Norton WT, Poduslo SE (1973) Myelination in rat brain: changes in myelin composition during brain maturation. J Neurochem 21 (4):759-773

27. Finean JB (1953) Phospholipid-cholesterol complex in the structure of myelin. Experientia 9(1):17-19

28. Cuzner ML, Davison AN, Gregson NA (1965) The chemical composition of vertebrate myelin and microsomes. J Neurochem 12(6):469-481 
29. Gopalakrishnan G, Awasthi A, Belkaid W, De Faria O Jr, Liazoghli D, Colman DR, Dhaunchak AS (2013) Lipidome and proteome map of myelin membranes. J Neurosci Res 91(3):321-334. https://doi.org/10. $1002 /$ jnr.23157

30. Thakurela S, Garding A, Jung RB, Muller C, Goebbels S, White R, Werner HB, Tiwari VK (2016) The transcriptome of mouse central nervous system myelin. Sci Rep 6:25828. https://doi.org/10.1038/srep25828

31. de Monasterio-Schrader P, Jahn O, Tenzer S, Wichert SP, Patzig J, Werner HB (2012) Systematic approaches to central nervous system myelin. Cell Mol Life Sci 69(17):2879-2894. https://doi.org/10.1007/s00018-012-09589

32. Manrique-Hoyos N, Jurgens T, Gronborg M, Kreutzfeldt M, Schedensack M, Kuhlmann T, Schrick C, Bruck W, Urlaub H, Simons M, Merkler D (2012) Late motor decline after accomplished remyelination: impact for progressive multiple sclerosis. Ann Neurol 71 (2):227-244. https://doi.org/10.1002/ana. 22681

33. Dagley LF, White CA, Liao Y, Shi W, Smyth GK, Orian JM, Emili A, Purcell AW (2014) Quantitative proteomic profiling reveals novel region-specific markers in the adult mouse brain. Proteomics 14(2-3):241-261. https:// doi.org/10.1002/pmic.201300196

34. Patzig J, Erwig MS, Tenzer S, Kusch K, Dibaj P, Mobius W, Goebbels S, SchaerenWiemers N, Nave KA, Werner HB (2016) Septin/anillin filaments scaffold central nervous system myelin to accelerate nerve conduction. Elife 5. https://doi.org/10.7554/eLife. 17119

35. Dumont D, Noben JP, Moreels M, Vanderlocht J, Hellings N, Vandenabeele F, Lambrichts I, Stinissen P, Robben J (2007) Characterization of mature rat oligodendrocytes: a proteomic approach. J Neurochem 102(2):562-576. https://doi.org/10.1111/j. 1471-4159.2007.04575.x

36. Iwata K, Cafe-Mendes CC, Schmitt A, Steiner J, Manabe T, Matsuzaki H, Falkai P, Turck CW, Martins-de-Souza D (2013) The human oligodendrocyte proteome. Proteomics 13(23-24):3548-3553. https://doi.org/10. 1002/pmic.201300201

37. Cassoli JS, Iwata K, Steiner J, Guest PC, Turck CW, Nascimento JM, Martins-de-Souza D (2016) Effect of MK-801 and clozapine on the proteome of cultured human oligodendrocytes. Front Cell Neurosci 10:52. https://doi. org/10.3389/fncel.2016.00052
38. Sharma K, Schmitt S, Bergner CG, Tyanova S, Kannaiyan N, Manrique-Hoyos N, Kongi K, Cantuti L, Hanisch UK, Philips MA, Rossner MJ, Mann M, Simons M (2015) Cell type- and brain region-resolved mouse brain proteome. Nat Neurosci 18(12):1819-1831. https://doi. org $/ 10.1038 / \mathrm{nn} .4160$

39. Werner HB, Jahn O (2010) Myelin matters: proteomic insights into white matter disorders. Expert Rev Proteomics 7(2):159-164

40. Farias AS, Pradella F, Schmitt A, Santos LM, Martins-de-Souza D (2014) Ten years of proteomics in multiple sclerosis. Proteomics 14 (4-5):467-480. https://doi.org/10.1002/ pmic. 201300268

41. Sherman DL, Brophy PJ (2005) Mechanisms of axon ensheathment and myelin growth. Nat Rev Neurosci 6(9):683-690

42. Simons M, Lyons DA (2013) Axonal selection and myelin sheath generation in the central nervous system. Curr Opin Cell Biol 25 (4):512-519. https://doi.org/10.1016/j. ceb.2013.04.007

43. Nave KA, Werner HB (2014) Myelination of the nervous system: mechanisms and functions. Annu Rev Cell Dev Biol 30:503-533. https:// doi.org/10.1146/annurev-cellbio-100913013101

44. Mobius W, Nave KA, Werner HB (2016) Electron microscopy of myelin: structure preservation by high-pressure freezing. Brain Res 1641 (Pt A):92-100. https://doi.org/10.1016/j. brainres.2016.02.027

45. Good NE, Winget GD, Winter W, Connolly TN, Izawa S, Singh RM (1966) Hydrogen ion buffers for biological research. Biochemistry 5 (2):467-477

46. Neuhoff V, Arold N, Taube D, Ehrhardt W (1988) Improved staining of proteins in polyacrylamide gels including isoelectric focusing gels with clear background at nanogram sensitivity using Coomassie Brilliant Blue G-250 and R-250. Electrophoresis 9(6):255-262. https://doi.org/10.1002/elps.1150090603

47. Patzig J, Jahn O, Tenzer S, Wichert SP, de Monasterio-Schrader P, Rosfa S, Kuharev J, Yan K, Bormuth I, Bremer J, Aguzzi A, Orfaniotou F, Hesse D, Schwab MH, Mobius W, Nave KA, Werner HB (2011) Quantitative and integrative proteome analysis of peripheral nerve myelin identifies novel myelin proteins and candidate neuropathy loci. J Neurosci 31(45):16369-16386. https://doi. org/10.1523/JNEUROSCI.4016-11.2011

48. Wessel D, Flugge UI (1984) A method for the quantitative recovery of protein in dilute 
solution in the presence of detergents and lipids. Anal Biochem 138(1):141-143

49. Taylor CM, Pfeiffer SE (2003) Enhanced resolution of glycosylphosphatidylinositolanchored and transmembrane proteins from the lipid-rich myelin membrane by two-dimensional gel electrophoresis. Proteomics 3(7):1303-1312. https://doi.org/10. 1002/pmic.200300451

50. Jahn O, Tenzer S, Bartsch N, Patzig J, Werner HB (2013) Myelin proteome analysis: methods and implications for the myelin cytoskeleton. NeuroMethods 79:335-353

51. Moche M, Albrecht D, Maass S, Hecker M, Westermeier R, Buttner K (2013) The new horizon in 2D electrophoresis: new technology to increase resolution and sensitivity. Electrophoresis 34(11):1510-1518. https://doi.org/ $10.1002 /$ elps.201200618

52. Distler U, Kuharev J, Navarro P, Tenzer S (2016) Label-free quantification in ion mobility-enhanced data-independent acquisition proteomics. Nat Protoc 11(4):795-812. https://doi.org/10.1038/nprot.2016.042

53. Wisniewski JR, Zougman A, Nagaraj N, Mann M (2009) Universal sample preparation method for proteome analysis. Nat Methods 6 (5):359-362

54. Distler U, Kuharev J, Tenzer S (2014) Biomedical applications of ion mobility-enhanced dataindependent acquisition-based label-free quantitative proteomics. Expert Rev Proteomics 11 (6):675-684. https://doi.org/10.1586/ 14789450.2014 .971114

55. Distler U, Kuharev J, Navarro P, Levin Y, Schild H, Tenzer S (2014) Drift time-specific collision energies enable deep-coverage dataindependent acquisition proteomics. Nat Methods 11(2):167-170. https://doi.org/ $10.1038 /$ nmeth.2767

56. Silva JC, Gorenstein MV, Li GZ, Vissers JP, Geromanos SJ (2006) Absolute quantification of proteins by LCMSE: a virtue of parallel MS acquisition. Mol Cell Proteomics 5 (1):144-156. https://doi.org/10.1074/mcp. M500230-MCP200

57. Lappe-Siefke C, Goebbels S, Gravel M, Nicksch E, Lee J, Braun PE, Griffiths IR, Nave KA (2003) Disruption of Cnpl uncouples oligodendroglial functions in axonal support and myelination. Nat Genet 33(3):366-374. https://doi.org/10.1038/ng1095

58. Edgar JM, McLaughlin M, Werner HB, McCulloch MC, Barrie JA, Brown A, Faichney AB, Snaidero N, Nave KA, Griffiths IR (2009) Early ultrastructural defects of axons and axonglia junctions in mice lacking expression of
Cnpl. Glia 57(16):1815-1824. https://doi. org/10.1002/glia.20893

59. Hagemeyer N, Goebbels S, Papiol S, Kastner A, Hofer S, Begemann M, Gerwig UC, Boretius S, Wieser GL, Ronnenberg A, Gurvich A, Heckers SH, Frahm J, Nave KA, Ehrenreich H (2012) A myelin gene causative of a catatonia-depression syndrome upon aging. EMBO Mol Med 4(6):528-539. https://doi.org/10.1002/emmm. 201200230

60. Sherman DL, Wu LM, Grove M, Gillespie CS, Brophy PJ (2012) Drp2 and periaxin form Cajal bands with dystroglycan but have distinct roles in Schwann cell growth. J Neurosci 32 (27):9419-9428. https://doi.org/10.1523/ JNEUROSCI.1220-12.2012

61. Domenech-Estevez E, Baloui H, Meng X, Zhang Y, Deinhardt K, Dupree JL, Einheber S, Chrast R, Salzer JL (2016) Akt regulates axon wrapping and myelin sheath thickness in the PNS. J Neurosci 36 (16):4506-4521. https://doi.org/10.1523/ JNEUROSCI.3521-15.2016

62. Yannakakis MP, Tzoupis H, Michailidou E, Mantzourani E, Simal C, Tselios T (2016) Molecular dynamics at the receptor level of immunodominant myelin oligodendrocyte glycoprotein 35-55 epitope implicated in multiple sclerosis. J Mol Graph Model 68:78-86. https://doi.org/10.1016/j.jmgm.2016.06. 005

63. Derfuss T, Parikh K, Velhin S, Braun M, Mathey E, Krumbholz M, Kumpfel T, Moldenhauer A, Rader C, Sonderegger P, Pollmann W, Tiefenthaller C, Bauer J, Lassmann $\mathrm{H}$, Wekerle $\mathrm{H}$, Karagogeos $\mathrm{D}$, Hohlfeld R, Linington C, Meinl E (2009) Contactin-2/TAG-1-directed autoimmunity is identified in multiple sclerosis patients and mediates gray matter pathology in animals. Proc Natl Acad Sci U S A 106 (20):8302-8307. https://doi.org/10.1073/ pnas.0901496106

64. Fewou SN, Fernandes A, Stockdale K, Francone VP, Dupree JL, Rosenbluth J, Pfeiffer SE, Bansal R (2010) Myelin protein composition is altered in mice lacking either sulfated or both sulfated and non-sulfated galactolipids. J Neurochem 112(3):599-610. https://doi. org/10.1111/j.1471-4159.2009.06464.x

65. Martins-de-Souza D (2011) Proteomics as a tool for understanding schizophrenia. Clin Psychopharmacol Neurosci 9(3):95-101. https://doi.org/10.9758/cpn.2011.9.3.95

66. Soong BW, Huang YH, Tsai PC, Huang CC, Pan HC, Lu YC, Chien HJ, Liu TT, Chang MH, Lin KP, Tu PH, Kao LS, Lee YC (2013) 
Exome sequencing identifies GNB4 mutations as a cause of dominant intermediate CharcotMarie-Tooth disease. Am J Hum Genet 92 (3):422-430. https://doi.org/10.1016/j. ajhg.2013.01.014

67. Larocca JN, Norton WT (2007) Isolation of myelin. Curr Protoc Cell Biol Chapter 3: Unit3.25

68. Menon K, Rasband MN, Taylor CM, Brophy P, Bansal R, Pfeiffer SE (2003) The myelinaxolemmal complex: biochemical dissection and the role of galactosphingolipids. J Neurochem 87(4):995-1009

69. Cammer W, Bieler L, Fredman T, Norton WT (1977) Quantitation of myelin carbonic anhydrase-development and subfractionation of rat brain myelin and comparison with myelin from other species. Brain Res 138(1):17-28

70. Danks DM, Matthieu JM (1979) Hypotheses regarding myelination derived from comparisons of myelin subfractions. Life Sci 24 (16):1425-1440

71. Sheads LD, Eby MJ, Sampugna J (1977) Myelin subfractions isolated from mouse brain. Studies of normal mice during development, quaking mutants, and three brain regions. J Neurobiol 8(1):67-89. https://doi.org/10. $1002 /$ neu.480080106

72. Kirschner DA, Inouye H, Ganser AL, Mann V (1989) Myelin membrane structure and composition correlated: a phylogenetic study. J Neurochem 53(5):1599-1609

73. Waehneldt TV (1990) Phylogeny of myelin proteins. Ann N Y Acad Sci 605:15-28

74. Roth AD, Ivanova A, Colman DR (2006) New observations on the compact myelin proteome. Neuron Glia Biol 2(1):15-21. https://doi. org/10.1017/S1740925X06000068

75. Baer AS, Syed YA, Kang SU, Mitteregger D, Vig R, Ffrench-Constant C, Franklin RJ, Altmann F, Lubec G, Kotter MR (2009) Myelin-mediated inhibition of oligodendrocyte precursor differentiation can be overcome by pharmacological modulation of Fyn-RhoA and protein kinase $\mathrm{C}$ signalling. Brain 132 (Pt 2):465-481. https://doi.org/10.1093/ brain/awn334

76. Ishii A, Dutta R, Wark GM, Hwang SI, Han DK, Trapp BD, Pfeiffer SE, Bansal R (2009)
Human myelin proteome and comparative analysis with mouse myelin. Proc Natl Acad Sci U S A 106(34):14605-14610. https:// doi.org/10.1073/pnas.0905936106

77. Nawaz S, Schweitzer J, Jahn O, Werner HB (2013) Molecular evolution of myelin basic protein, an abundant structural myelin component. Glia 61(8):1364-1377

78. Morris JK, Willard BB, Yin X, Jeserich G, Kinter M, Trapp BD (2004) The 36K protein of zebrafish CNS myelin is a short-chain dehydrogenase. Glia 45(4):378-391. https://doi. org/10.1002/glia.10338

79. Schaefer K, Brosamle C (2009) Zwilling-A and $-B$, two related myelin proteins of teleosts, which originate from a single bicistronic transcript. Mol Biol Evol 26(3):495-499. https:// doi.org/10.1093/molbev/msn298

80. Luo S, Wehr NB, Levine RL (2006) Quantitation of protein on gels and blots by infrared fluorescence of Coomassie blue and Fast Green. Anal Biochem 350(2):233-238. https://doi.org/10.1016/j.ab.2005.10.048

81. Harris LR, Churchward MA, Butt RH, Coorssen JR (2007) Assessing detection methods for gel-based proteomic analyses. J Proteome Res 6(4):1418-1425. https://doi.org/10. $1021 / \mathrm{pr} 0700246$

82. Schmidt C, Hesse D, Raabe M, Urlaub H, Jahn O (2013) An automated in-gel digestion/ iTRAQ-labeling workflow for robust quantification of gel-separated proteins. Proteomics 13 (9):1417-1422. https://doi.org/10.1002/ pmic. 201200366

83. Viswanathan S, Unlu M, Minden JS (2006) Two-dimensional difference gel electrophoresis. Nat Protoc 1(3):1351-1358

84. Tannu NS, Hemby SE (2006) Two-dimensional fluorescence difference gel electrophoresis for comparative proteomics profiling. Nat Protoc 1(4):1732-1742. https://doi.org/10.1038/nprot.2006.256

85. Jahn O, Hesse D, Reinelt M, Kratzin HD (2006) Technical innovations for the automated identification of gel-separated proteins by MALDI-TOF mass spectrometry. Anal Bioanal Chem 386(1):92-103. https://doi. org/10.1007/s00216-006-0592-1 